\title{
Nitrogen fertilization in narrow row cotton productivity in second harvest
}

\section{Adubação nitrogenada na produtividade de algodoeiro adensado em segunda safra}

\section{Monica Cristina Rezende Zuffo BORGES ${ }^{1}$; Eduardo Pradi VENDRUSCOLO²; Cassiano Garcia ROQUE'; Aguinaldo José Freitas LEAL ${ }^{3}$; Felipe Barbosa de FREITAS ${ }^{4}$}

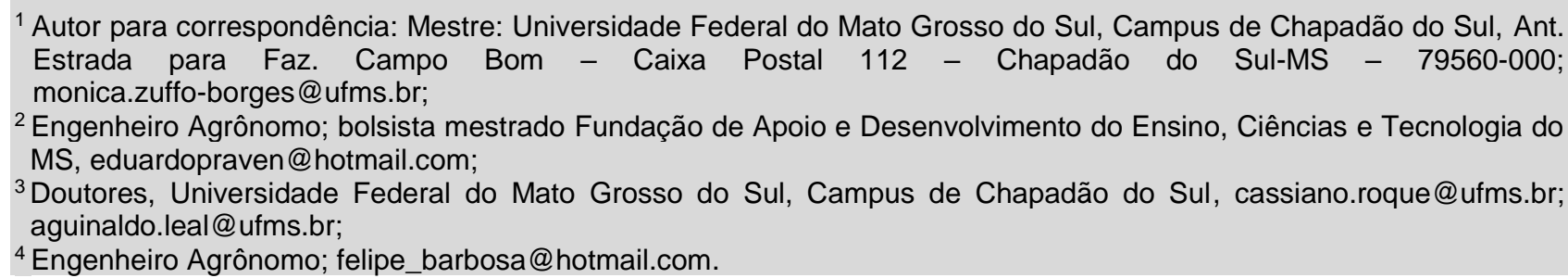

Recebido em: 03-07-2014; Aceito em: 27-05-2015

\begin{abstract}
The narrow row cotton grown in the second harvest is presented as an alternative in order to reduce cost of production due to lower cycle. However, nitrogen fertilization in this growing season is little studied. The objective was to evaluate the effect of nitrogen in narrow row cotton crop, grown in second harvest after bean. The experiments were set in a randomized block design with 4 treatments and 5 repetitions in the agricultural years 2009/10 and 2010/11. The treatments consisted of nitrogen application in coverage broadcasted in the form of urea at rates of $60,80,100$ and $120 \mathrm{~kg} \mathrm{ha}^{-1} \mathrm{~N}$ in two years of cultivation. It was concluded that the nitrogen rate of approximately $85 \mathrm{~kg} \mathrm{ha}^{-1}$ applied in coverage in narrow row cotton, grown in second season, increases the number of bolls per plant, boll mass and cotton yield productivity.
\end{abstract}

Additional keywords: calibration curve, yield; cultural practices; Gossypium hirsutum L.; Savanna.

\section{Resumo}

O algodoeiro adensado cultivado em segunda safra apresenta-se como uma alternativa visando redução de custo de produção, pois apresenta menor ciclo. Entretanto, a adubação nitrogenada nessa época de cultivo é pouco estudada. Objetivou-se avaliar o efeito de doses de nitrogênio na cultura do algodoeiro adensado, cultivado em segunda safra após feijoeiro. Os ensaios foram instalados em blocos ao acaso, com 4 tratamentos e 5 repetições, nos anos agrícolas 2009/10 e 2010/11. Os tratamentos consistiram na aplicação de nitrogênio em cobertura a lanço sob a forma de ureia nas doses de 60, 80, 100 e $120 \mathrm{~kg} \mathrm{ha}^{-1}$ de $\mathrm{N}$ em dois anos de cultivo. Concluiu-se que a dose de nitrogênio de aproximadamente $85 \mathrm{~kg} \mathrm{ha}^{-1}$ aplicada em cobertura em algodoeiro adensado, cultivado em segunda safra, incrementa o número de capulhos por planta, massa de capulhos e a produtividade de algodão em caroço.

Palavras-chave adicionais: cerrado; curva de calibração; Gossypium hirsutum L.; Práticas Culturais.

\section{Introduction}

Cotton plant (Gossypium hirsutum L.) belongs to the Malvaceae Family and is among the most important fiber crops in the world. Every year, an average of 35 million hectares of cotton is grown around the world with a global production estimate of 25.2 million tons of seed cotton for the 2014-2015 crop (ABRAPA, 2014). Cotton is produced by more than 60 countries, being China, India, United States, Pakistan and Brazil the major producers of the fiber. From August 2013 to June 2014, Brazil exported about 141 thousand tons of plume, generating a revenue of US\$275 million (CONAB, 2014).

Cotton crop in the Cerrado region began as an alternative crop rotation to soybeans. This region has suitable conditions for crop development with flat topography, climate and soil conditions with well defined seasons and good rainfall distribution (Carvalho et al., 2007), as well as soils with fertility corrected after successive soybean crops.

Brazilian cotton cultivation has reached high levels of productivity. However, in order to consolidate it, it is necessary to reduce economic and ecological risks and increase profitability by reducing costs. Narrow Row Cotton (NRC) grown as second harvest in Cerrado, after harvesting of early cycle soybeans or beans, and sown during the month of January and first half of February (Freire, 2011), aims to reduce row spacing and increase plant density. This new technology has been gaining space in recent years for making the production system more competitive, 
reducing the crop cycle and the cost of production and thereby ensuring greater economic return per area/year of cultivation compared to cotton crop only in regular harvest (Silva et al., 2009).

Narrow row cotton cultivation in second harvest, preceded by a legume (beans or soybeans) in summer, has been used by farmers (Silva, 2011), increasing the producer's income by having two annual crops in the same agricultural year (Beltrão et al., 2001). Cotton crop after the bean cultivation becomes an advantageous system, for it combines a fast-cycle legume, which will accumulate nitrogen in its roots and would later make it available to the next culture, promoting the cotton plant growth.

The use of narrow row cotton cultivation system makes prohibitive the use of large amounts of $\mathrm{N}$, due mainly to the reduction of rainfall and the decrease in average air temperature from May in Mato Grosso (Freire, 2011). However, N rates in narrow row system should be adjusted to prevent excessive growth, delayed maturity and to obtain good fiber quality. Usually, $\mathrm{N}$ rates in narrow row system do not differ from the ones required in the conventional system, and $\mathrm{N}$ applications up to $112 \mathrm{~kg} \mathrm{ha}^{-1}$ are sufficient to achieve good productivity values (Feltrin, 2007). Reduction in the amounts of $N$ will be performed according to the objectives in the proposed narrow row system, with crop cycle reduction, lower vegetative growth, lack of decay of the first bolls and possible nitrogen contribution from the previous crop in case it is a legume (Carvalho et al., 2007).

The objective was to evaluate the effect of nitrogen rates on the production and the narrow row cotton yield components, grown in second harvest after bean cultivation in Cerrado conditions.

\section{Material and methods}

The experiment was conducted in the experimental area of the Federal University of Mato Grosso do Sul (UFMS), Chapadão do Sul Campus (CPCS), located in the city of Chapadão do Sul/MS, in the agricultural years of 2009-2010 and 2010-2011. The site has an average altitude of $810 \mathrm{~m}$ and is located in the following geographical coordinates: latitude 18 $41^{\prime}$ '33" South and Longitude 52 $40^{\prime}$ '45" West. The predominant climate is tropical humid $(A w)$, with rainy season in summer and dry season in winter and average annual rainfall of $1,850 \mathrm{~mm}$, average annual temperature ranging between $13 \stackrel{\circ}{\circ} \mathrm{C}$ and $28 \stackrel{\circ}{ } \mathrm{C}$. The soil of the experimental area was classified as typical Oxisol with a clay-like texture
(435 $\mathrm{g} \mathrm{dm}^{-3}$ clay, $25 \mathrm{~g} \mathrm{dm}^{-3}$ silt and $540 \mathrm{~g} \mathrm{dm}^{-3}$ sand), according to the Brazilian Soil Classification System (EMBRAPA, 2006). Table 1 shows the results of the soil chemical analysis in the layer $0-0.20 \mathrm{~m}$, sampled in beginning of the experiment.

Sowing was carried out on February 15th and 5th, respectively, in 2009 and 2010. Air temperature values and rainfall index during the months of experiment conduction are presented in Figure 1 beyond the main cultural practices.

Treatments consisted of nitrogen fertilization doses in coverage performed at 30 days after plant emergence (field B1). The $\mathrm{N}$ source used was urea $(45 \% \mathrm{~N})$ and the treatments used were as follows: 60 $\mathrm{kg} \mathrm{ha}^{-1} \mathrm{~N} ; 80 \mathrm{~kg} \mathrm{ha}^{-1} \mathrm{~N} ; 100 \mathrm{~kg} \mathrm{ha}^{-1} \mathrm{~N} ; 120 \mathrm{~kg} \mathrm{ha}^{-1} \mathrm{~N}$, applied by throwing without incorporation. Thus, the experiment was installed in the first half of February in the years 2010 and 2011 (sowings made on February 15th and 5th, respectively, in 2009 and 2010), using the cultivar FiberMax 993. The experimental design was randomized blocks, with 4 treatments and 5 replications and the experimental plot had 7 lines of $10 \mathrm{~m}$ long, $0.45 \mathrm{~m}$ spacing, with 12 plants per linear meter, totaling $31.5 \mathrm{~m}^{2}$ per plot, the useful area consisted of the three central rows of 6 meters long.

Production system used was no-tillage with bean crop succession, grown in the summer crop. According to the crop needs in the field, there have been applications of insecticides, fungicides, herbicides and also manual control of remaining beggarticks plants. In addition to the application of plant growth regulators, mepiquat chloride (50 $\mathrm{g}$ i.a ha ${ }^{-1}$ ), in the field B3 (03/30/10 and 03/25/11).

The following agronomic characteristics were assessed at 110 days after emergence: stem diameter, plant height, number of branches/plant and number of bolls. At the end of the experiment, the number of bolls, the number of cotton bolls and the weight of 100 cotton bolls, randomly picked in the middle third of the plants and weighed on digital scales, have been counted. Cotton productivity in seed was obtained through manual harvesting of the three central rows of each plot and was later extrapolated to $\mathrm{kg} \mathrm{ha}^{-1}$.

The experiment was analyzed in split plot scheme: 2 years of evaluation (plot) and 4 nitrogen rates (subplot). The results were submitted to analysis of variance. Regression analysis was held for the rates and Tukey test $(p<0.05)$ was performed with the help of computer system SISVAR, developed by Ferreira (2011), to evaluate the influence of years of cultivation.

Table 1 - Results of chemical analysis of soil in the experimental area at depths $0-0.20 \mathrm{~m}$, in 2009 and 2010, Chapadão do Sul-MS, CPCS/UFMS.

\begin{tabular}{lcccccccccc}
\hline Year & $\begin{array}{c}\text { Depth } \\
(\mathrm{m})\end{array}$ & $\begin{array}{c}\mathrm{pH} \\
\mathrm{CaCl}_{2}\end{array}$ & $\begin{array}{c}\mathrm{P} \\
\left(\mathrm{mg} \mathrm{dm}^{-3}\right)\end{array}$ & $\begin{array}{c}\mathrm{K} \\
-\end{array}$ & $\begin{array}{c}\mathrm{Ca} \\
\mathrm{-n}\end{array}$ & $\begin{array}{c}\mathrm{Mg} \\
\mathrm{H}+\mathrm{Al}\end{array}$ & $\mathrm{S} . \mathrm{B}$ & $\mathrm{CTC}$ & $\begin{array}{c}\text { M.O. } \\
\left(\mathrm{g} \mathrm{dm}^{-3}\right)\end{array}$ \\
\hline $2009-2010$ & $0-0.20$ & 4.5 & 6.7 & 0.18 & 2.83 & 0.55 & 5.98 & 37.29 & 9.54 & 23.6 \\
$2010-2011$ & $0-0.20$ & 4.7 & 7.8 & 0.25 & 3 & 0.51 & 6.80 & 35.50 & 10.6 & 26.8 \\
\hline
\end{tabular}




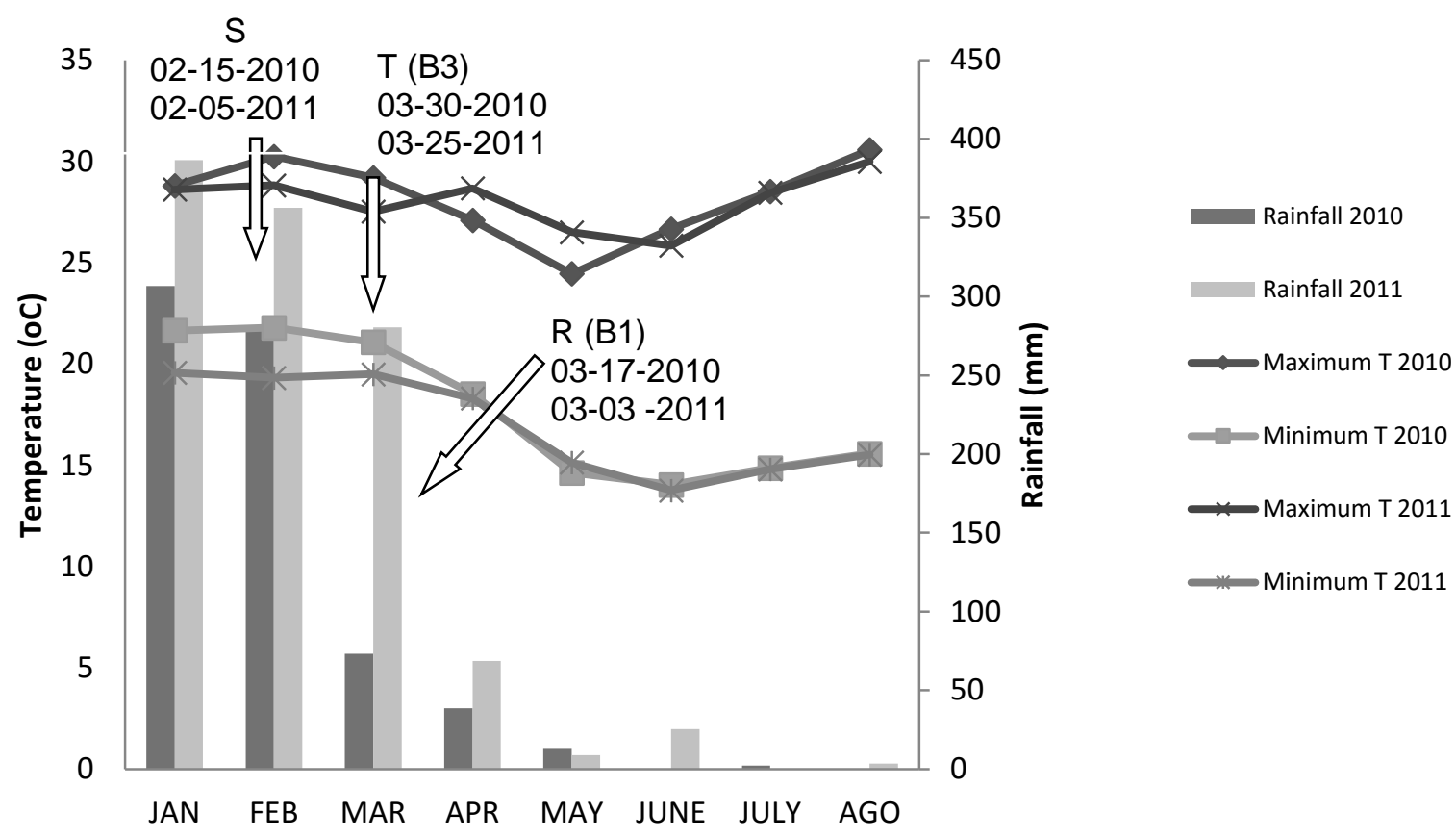

Figure 1 - Rainfall and average maximum and minimum temperature occurred during the experiments in Chapadão do Sul, MS, in 2010 and 2011. Source: Fazenda Campo Bom and Fundação Chapadão. Sowing (S), Topdressing (T); Growth Regulator (R).

\section{Results and discussions}

Nitrogen rates influenced: the number of cotton bolls/plant, the average weight of 100 cotton bolls and seed cotton productivity (Tables 2 and 3 ). Comparing the crop years 2009-2010 and 2010-2011, there were differences in the plant diameter, plant height and number of cotton bolls/plant. Characteristics number of branches and number of bolls were not affected by the nitrogen rates in both agricultural years. No attribute showed a significant interaction between the factors nitrogen rate and years of cultivation.

Table 2 - Average data and $F$ values obtained for plant diameter $(\mathrm{cm})$, plant height $(\mathrm{m})$, number of branches/plant and number of bolls/plant depending on the nitrogen rates in the crop years (2009/10) and (2010-2011) in Chapadão do Sul-MS, UFMS/CPCS ${ }^{1}$.

\begin{tabular}{lcccc}
\hline Sources of variation & Diameter $(\mathrm{cm})$ & Height $(\mathrm{m})$ & $\begin{array}{c}\text { Number of } \\
\text { branches }\end{array}$ & Number of bolls \\
\hline Year $(\mathrm{A})$ & & & & \\
$2009-2010$ & $7.21 \mathrm{a}$ & $0.43 \mathrm{~b}$ & 7.74 & 2.94 \\
$2010-2011$ & $6.00 \mathrm{~b}$ & $0.46 \mathrm{a}$ & 8.12 & 3.10 \\
\hline $\mathrm{N}$ rate $\left(\mathrm{kg} \mathrm{ha}^{-1}\right)(\mathrm{D})$ & & & & \\
60 & 6.27 & 0.44 & 7.80 & 2.84 \\
80 & 6.67 & 0.45 & 8.06 & 3.26 \\
100 & 7.90 & 0.47 & 8.14 & 3.44 \\
120 & 6.40 & 0.43 & 7.72 & 2.54 \\
\hline $\mathrm{F}(\mathrm{A})$ & $73.92^{\star *}$ & $30.19^{* *}$ & $3.03^{\mathrm{ns}}$ & $0.56^{\mathrm{ns}}$ \\
$\mathrm{F}(\mathrm{D})$ & $1.90^{\mathrm{ns}}$ & $1.76^{\mathrm{ns}}$ & $0.37^{\mathrm{ns}}$ & $2.01^{\mathrm{ns}}$ \\
$\mathrm{F}\left(\mathrm{A}^{\star} \mathrm{D}\right)$ & $0.15^{\mathrm{ns}}$ & $0.83^{\mathrm{ns}}$ & $0.001^{\mathrm{ns}}$ & $0.26^{\mathrm{ns}}$ \\
\hline CV - Year $(\%)$ & 6.72 & 4.34 & 8.70 & 22.42 \\
CV - N rate $(\%)$ & 12.77 & 8.93 & 13.21 & 21.70 \\
\hline
\end{tabular}

${ }^{1}$ Means followed by different letters in the column differ at $1 \%$ probability by Tukey test. ${ }^{n s}$ not significant. ${ }^{*}$ significant at $1 \%$ probability by $\mathrm{F}$ test.

Although the nitrogen rates have not influenced the diameter and height of cotton plants, these characteristics have changed over the years of cultivation. In the first year, the plant height was lower, the diameter, however, was greater. In 2009-2010, the plants had an average diameter of $7.21 \mathrm{~cm}$, while in 
the year 2010-2011 it was $6.00 \mathrm{~cm}$. Regarding the final plant height, the average of $2010-2011$ was $0.46 \mathrm{~m}$, while in the year 2009-2010, the value was $0.43 \mathrm{~m}$. These heights are considered low, even for narrow row cultivation of cotton. In this system, it is recommended an average height of up to $0.70 \mathrm{~m}$ (Freire, 2011), enabling a mechanized harvest of narrow row cotton (Belot et al., 2002). Although plant density and nitrogen fertilization increase plant height (Marinho et al., 2011; Sofiatti et al., 2011), no excessive growth was shown in both years, even at the highest nitrogen rates, and only one application of plant growth regulator was needed. This was due to the cultivation of second harvest, with sowing performed in the first half of February each year.

The average rainfall for cultivation and conventional cotton production, depending on the weather and the cycle time, according to Meneses (2007), is $700-1300 \mathrm{~mm}$ of rain, to meet their water needs. Of this total, 50 to $60 \%$ is needed during the flowering period. Although the water requirement for narrow row cotton cultivation is not defined, the greatest demand is also expected to occur during the flowering stages of narrow row cotton (30-40 days).

Table 3 - Average data and F values obtained for number of bolls/plant, average weight of 10 bolls $(\mathrm{g})$ and yield of cotton $\left(\mathrm{kg} \mathrm{ha}^{-1}\right)$ depending on the nitrogen rates in crop years (2009/10) and (2010/11), in Chapadão do Sul-MS, UFMS/CPCS ${ }^{1}$.

\begin{tabular}{lccc}
\hline Sources of variation & Number of Bolls & Average boll weight $(\mathrm{g})$ & Yield $\left(\mathrm{kg} \mathrm{ha}^{-1}\right)$ \\
\hline Year $(\mathrm{A})$ & & & \\
$2009 / 2010$ & $2.67 \mathrm{~b}$ & 3.42 & 741.12 \\
$2010 / 2011$ & $4.00 \mathrm{a}$ & 3.53 & 734.91 \\
\hline $\mathrm{N}$ rate $\left(\mathrm{kg} \mathrm{ha}^{-1}\right)(\mathrm{D})$ & & & \\
60 & 3.28 & 3.43 & 711.41 \\
80 & 3.58 & 3.60 & 845.96 \\
100 & 3.74 & 3.63 & 844.46 \\
120 & 2.74 & 3.25 & 550.24 \\
\hline $\mathrm{F}(\mathrm{A})$ & $35.27^{* *}$ & $1.73^{\mathrm{ns}}$ & $0.034^{\mathrm{ns}}$ \\
$\mathrm{F}(\mathrm{D})$ & $3.83^{*}$ & $8.95^{\star *}$ & $26.12^{\star *}$ \\
$\mathrm{~F}\left(\mathrm{~A}^{*} \mathrm{D}\right)$ & $0.03^{\mathrm{ns}}$ & $2.22^{\mathrm{ns}}$ & $0.47^{\mathrm{ns}}$ \\
\hline CV - Year $(\%)$ & 21.23 & 7.77 & 14.34 \\
CV $-\mathrm{N}$ rate & 21.33 & 5.39 & 11.75 \\
\hline
\end{tabular}

${ }^{1}$ Means followed by different letters in the column differ at $5 \%$ probability by Tukey test. : ${ }^{n s} ;{ }^{*} e^{* *}$ not significant, significant at $5 \%$ probability and significant at $1 \%$ probability by $\mathrm{F}$ test, respectively.

The number of cotton bolls per plant was affected by nitrogen rates and also by the years of narrow row cotton cultivation (Table 3). In 2010-2011, crop provided average values of 4 bolls per plant, values higher than shown in the 2009/10 crop (2.67 bolls/plant). In both years, the average number of cotton bolls per plant was higher than that obtained by Silva et al. (2011) in narrow row cotton grown in the state of São Paulo (2.35). However, it was lower (6.2) than that observed by Kaneko et al. (2014) in narrow row cotton sown in early January, close to the experimental area, but getting higher volume of rainfall (about $1050 \mathrm{~mm}$ ). Therefore, the larger number of cotton bolls per plant in the 2010-2011 crop is related to the better distribution and higher volume of rainfall, approximately $710 \mathrm{~mm}$. While in 2009-2010 rainfall was $360 \mathrm{~mm}$. Therefore, the number of cotton bolls per plant narrow row cotton grown in second harvest in the Cerrado region is influenced by rainfall.

Regarding $\mathrm{N}$ rates, there was an adjustment to a quadratic model, with point of maximum number of cotton bolls on the estimated rate of $84.19 \mathrm{~kg} \mathrm{ha}^{-1} \mathrm{~N}$, reaching the maximum value of 3.65 bolls/plant (Figure
2). To Sofiatti et al., (2011) narrow row cotton must show 4 to 5 cotton bolls per plant, but productivity should not be changed, since the plant population is double the conventional. Similar values were obtained by Kaneko et al. (2011), who analyzed the nitrogen fertilization in narrow row cotton growing in the Chapadões region and observed increase in the number of bolls/plant to the rate of $80 \mathrm{~kg} \mathrm{ha}^{-1} \mathrm{~N}$.

Significant effect of nitrogen rates was observed on average weight of 100 cotton bolls (Table 3). By adjusting it to the quadratic model, there was an increase to the rate of $87.14 \mathrm{~kg} \mathrm{ha}^{-1} \mathrm{~N}$ (Figure 2). However, Mcconnell et al. (2008), in a trial evaluating $\mathrm{N}$ rates on cotton in narrow row cultivation for four years, found increases in the weight of bolls in only two of them, with increases up to $56 \mathrm{~kg} \mathrm{~N}^{-1}$. According to these authors, the effect of $\mathrm{N}$ rates on the weight of bolls in narrow row cotton has interaction with the cultivation environment. However, this interaction was not observed in the present study (Table 3). The weight of 100 cotton bolls and the number of cotton bolls per plant reduce with increasing population density. However, a suitable plant population balances 
this relationship, enabling higher yields (Anselmo et al., 2011). According Lamas (2001), the weight of cotton bolls is directly influenced by the balance between vegetative and reproductive parts of the plant, thus indicating that the nitrogen fertilization has altered this balance. This fertilization enabled increases in the weight of cotton bolls, as seen in this study, at $\mathrm{N}$ rate lower than $87 \mathrm{~kg} \mathrm{ha}^{-1} \mathrm{~N}$, considered appropriate to the balance between vegetative and reproductive part of narrow row cotton, sown in February. Higher nitrogen rates $\left(120 \mathrm{~kg} \mathrm{ha}^{-1}\right)$ promote an imbalance in the plant, drastically reducing the weight of cotton bolls and consequently the production (Figure 2). Even with the adoption of plant growth regulator.

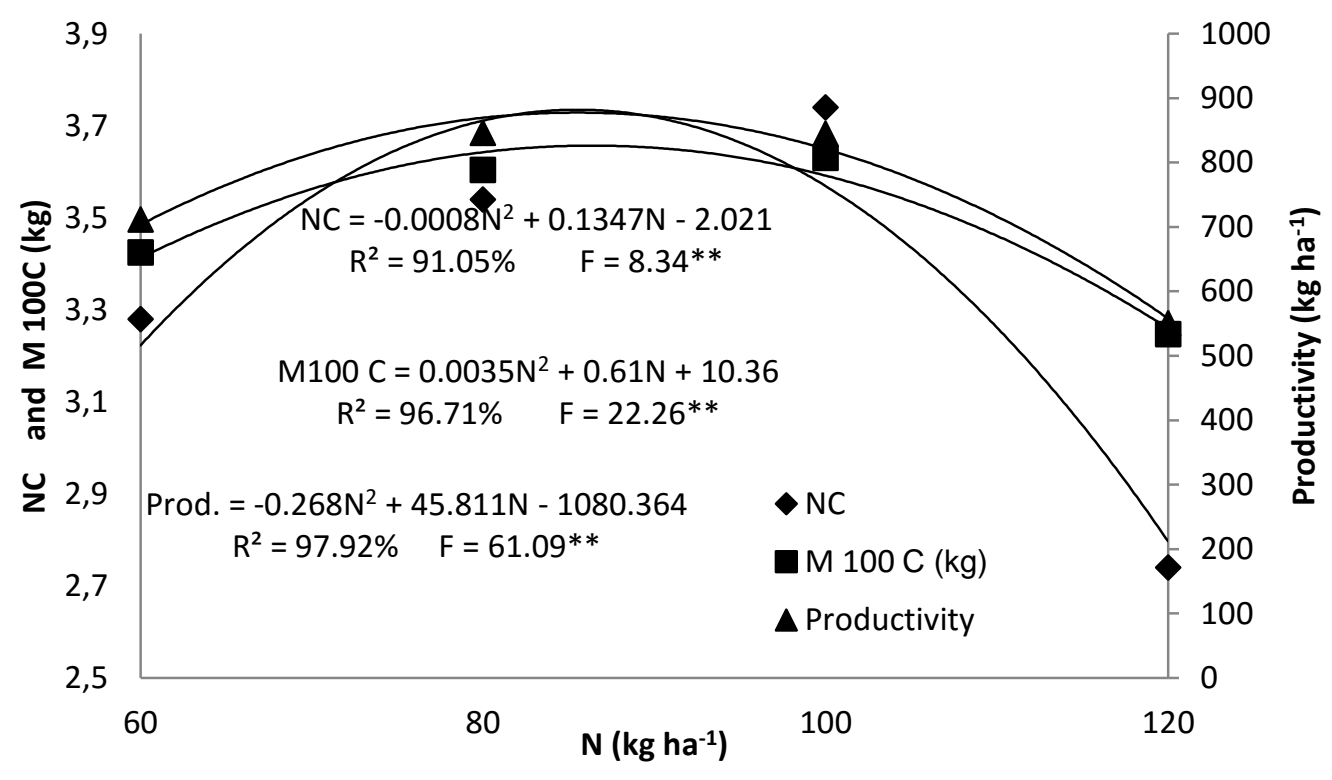

Figure 2 - Number of bolls/plant (NC), average weight of bolls (M $100 \mathrm{C} ; \mathrm{kg}$ ), seed cotton productivity (Prod.; $\mathrm{kg} \mathrm{ha}^{-1}$ ) of narrow row cotton depending on the application of nitrogen rates in crop years (2009-2010) and (2010- 2011) in Chapadão do Sul-MS, UFMS/CPCS. * $\mathrm{e}^{* *}$ not significant, significant at $5 \%$ probability and significant at $1 \%$ probability by $\mathrm{F}$ test.

Seed cotton yield was significantly influenced by nitrogen rates in coverage (Table 3 ), with no interaction with years of cultivation. A quadratic adjustment was made with increments until the rate of $85.47 \mathrm{~kg} \mathrm{ha}^{-1} \mathrm{~N}$. Similar values were obtained by Bogiani et al. (2011), by testing nitrogen rates on cotton plant in narrow row cultivation in São Desidério-BA. These authors obtained maximum productivity in narrow row system with use of $80 \mathrm{~kg} \mathrm{ha}^{-1} \mathrm{~N}$. Rinehardt et al. (2004) also suggested that the optimum production rate narrow row cultivation was achieved with $90 \mathrm{~kg} \mathrm{ha}^{-1} \mathrm{~N}$.

The results were similar to those obtained and recommended by Anselmo \& Leal (2010), by emphasizing that narrow row cotton does not require application of nitrogen rates different from the ones of conventional cotton, and applications up to $112 \mathrm{~kg} \mathrm{ha}^{-1}$ $\mathrm{N}$ are sufficient to achieve maximum yield. In the same vein, Silva et al. (1986), studying nitrogen fertilization in conventional cotton plant, found a productivity increase up to the rate of $88 \mathrm{~kg} \mathrm{ha}^{-1} \mathrm{~N}$. However, due to the large influence of climate conditions on cotton production, the economic $\mathrm{N}$ rate to be adopted depends on the productive potential of culture.

Anselmo et al. (2011), comparing four different sowing seasons in narrow row system, found satisfying answers in narrow row cotton productivity in the region of Chapadões when sown until end of January. Immediately after this period, there was a significant decrease in productivity, mainly due to the lack water and low temperatures during flowering and filling of the cotton fruits. The fact was confirmed in this study in both evaluated agricultural years, in which productivity was limited by low rainfall occurred during the phases of boll formation, reflecting low weight of cotton bolls and fewer number of cotton bolls per plant when compared to sowing in early January performed by Kaneko et al. (2014). The high risks of narrow row cotton cultivation in second harvest should be emphasized, as the low rainfall occurred after 70 days of plant emergence contributes significantly to reduced productivity, which brings a high risk to narrow row cotton cultivation in the Chapadões region (Morello et al., 2009). Thus, this study revealed the low productive potential of cotton sown in second harvest, in the first half of February, even in narrow row system. Especially due to the low rainfall occurred in April and May in both years of evaluation (Figure 1).

There are few studies in the literature involving the nitrogen calibration curve for narrow row cotton cultivation, especially in second harvest, in the altitude Cerrado region. One of the first studies was done by 
Anselmo \& Leal (2010), who have evaluated $\mathrm{N}$ rates in narrow row system in the same region and found productivity response until the rate of $120 \mathrm{~kg} \mathrm{ha}^{-1} \mathrm{~N}$. However, the same authors recommended rates of up to $100 \mathrm{~kg} \mathrm{ha}^{-1} \mathrm{~N}$, seeking greater economic return and plant height more suitable for mechanical harvest with Stripper type harvester, indicated for cotton harvest in narrow row system. According to Silva et al. (2005), Stripper type harvesters have a high level of losses, which can practically impair their use in cotton harvest in production systems producing high size plants. Furthermore, in conventional crop, Rosolem (2001) reported that rates above 100 to $120 \mathrm{~kg} \mathrm{ha}^{-1} \mathrm{~N}$ would hardly be economical based on results obtained in traditional growing regions in Brazil.

Also according Rosolem (2001), an important aspect of the cotton crop is that sowing in early February increases the risk of reduction in the amount and quality of narrow row cotton, since it is directly influenced by low temperatures. According to the author, who uses historical average rainfall and temperature data of the Chapadão do Sul region, even if the rainy season is long and sufficient for the fruit development and maturation, which was not seen in the two years of conducting this study, the temperature is not suitable. This is because a large part of growth, especially maturation, takes place in May, when night temperatures are often below $15^{\circ} \mathrm{C}$, far below the optimum temperature. This fact was observed in both crop years (Figure 1). Thus, besides increasing the risk of obtaining low productivity and also the reduction in cotton plant quality in relation to macronair and resistance below desired, low temperatures may provide the elongation of the crop cycle.

Therefore, narrow row cotton cultivation in second harvest, sown after the first half of February, should be avoided in the Chapadão do Sul region, since the reduction of rainfall and temperature in April and May (Figure 1), respectively, reduces productivity. Productivity mentioned above is much lower than that offered by narrow row cotton sown in early January, as obtained by Kaneko et al. (2014), approximately $2400 \mathrm{~kg} \mathrm{ha}^{-1}$. Furthermore, rates higher than $100 \mathrm{~kg} \mathrm{~N}$ per ha $\mathrm{h}^{-1}$ shall not be adopted for providing unbalance between vegetative and reproductive part of the plant, reducing the number of cotton bolls per plant, the weight of cotton bolls and cotton yield (Figure 2).

\section{Conclusions}

Nitrogen rate of approximately $85 \mathrm{~kg} \mathrm{ha}{ }^{-1}$ applied in coverage in narrow row cotton, grown in second harvest after summer beans in the Cerrado, increases the number of cotton bolls per plant, the weight of cotton bolls and seed cotton productivity.

Regardless of the evaluated year of cultivation, sowing of narrow row cotton in February, in altitude cerrado region, provides low production of seed cotton, when this region has low rainfall and average minimum temperature below $15^{\circ} \mathrm{C}$, respectively, in April and May.

\section{References}

ABRAPA - Associação Brasileira dos Produtores de Algodão (2014) Disponível em: <http://www.abrapa.com.br> (Acesso em: 25 jun. 2014).

Anselmo JL, Holanda HV, Leonel TZ, Magalhães HJS, Dias AR, Leal AJF (2011) Efeito da densidade de semeadura sob sistema adensado em diferentes Variedades de algodão na região dos chapadões. In: Congresso Brasileiro do Algodão, 8. Anais... CD-ROM. Anselmo JL, Leal AJF (2010) Algodão: Adensado na safrinha. Cultivar Grandes Culturas, 12:40-42.

Bogiani JC, Ferreira GB, Smiderle OJ, Júnior MM, Borin ALDC (2011) Adubação com potássio e nitrogênio de cultivares de algodoeiro sob sistema de cultivo adensado. In: Congresso Brasileiro do Algodão, 8, Anais... 1451-1458p. CD-ROM.

Belot JL, Martin J, Vilela PA, Marques A, Rodrigo M (2002) Avaliação dos sistemas de cultivo do algodão em linhas estreitas (NRC) ou ultra estreitas (UNRC) com um protótipo de colheitadeira "stripper" fabricado no Brasil FACUAL/Unicotton, 35: 52p.

Beltrão NEM, Pereira JR, Oliveira JN (2001) Consorciação algodoeiro herbáceo e gergelim: efeitos dos fatores cultivares, configurações de plantio e épocas relativas de plantio. Congresso Brasileiro do Algodão, 3. Anais ... Campo Grande. CD-ROM.

Carvalho MCS, Ferreira GB, Santos FC. (2007) Manejo de solo e respostas do algodoeiro à calagem e adubação na Região de cerrados de Goiás e Bahia. Congresso Brasileiro do Algodão, 6. Anais... Uberlândia. 1. CD-ROM.

CONAB. Acompanhamento de safra brasileira: grãos, terceiro levantamento. (2014) Disponível em: <http:// www.conab.gov.br.> (Acesso em: 12 dez. 2014)

EMBRAPA (2006) Sistema brasileiro de classificação de solos. 2. ed. Rio de Janeiro, $306 \mathrm{p}$.

Feltrin EB (2007). Produtividade e qualidade de fibra de cultivares de algodoeiro em função de doses de nitrogênio. - UNESP (Dissertação Mestrado).

Ferreira DF (2011) Sisvar: a computer statistical analysis system. Ciência e Agrotecnologia, 35(6): 1.039-1.042p.

Freire EC (2011) Algodão no Cerrado do Brasil. Associação Brasileira de Produtores de Algodão. 1082 p.

Kaneko FH, Holanda HV, Leal AJF, Roque CG, Dias AR, Franzote FH (2011) Adubação nitrogenada em algodão adensado na região dos chapadões. In: CONGRESSO BRASILEIRO DE ALGODÃO, 8, Anais... 1669-1675p. CD-ROM. 
Kaneko FH, Leal AJF, Dias AR, Anselmo JL, Buzetti S, Dal Bem EA, Gitti DC, Nascimento V (2014) Resposta do algodoeiro em cultivo adensado a doses de nitrogênio, fósforo e potássio. Revista Agrarian 7(25): 382-389.

Lamas FM (2001) Estudo comparativo entre cloreto de mepiquat e cloreto de chlormequat aplicados no algodoeiro. Pesquisa Agropecuária Brasileira, 36(21): 227-233.

Marinho JF, Veiga F, Ferrari S, Júnior EF (2011) Avaliação do desenvolvimento vegetativo do algodoeiro submetido a adensamento e manejo de regulador de crescimento. CONGRESSO BRASILEIRO DO ALGODÃO, 8. Anais ... Campina Grande : CD - ROM.

McConnell JS, Francis PB, Stark CR, Glover RE (2008) Plant responses of ultra narrow row cotton to nitrogen fertilization. Journal of Plant Nutrition, 31: 1005-1017.

Meneses CHSG (2007) Potencial hídrico induzido por polietilenoglicol-6000 na qualidade fisiológica de sementes de algodão. UFPB (Tese de Mestrado).

Morello CL, Suassuna ND, Ferreira ACB, Bezerra W (2009) Desempenho de linhagens de algodoeiro em cultivo adensado e em safrinha. In: CONGRESSO BRASILEIRO DO ALGODÃO, 7. Anais... 1593-1598.

Rinehardt JM, Edmisten KL, Wells R (2004) Response of Ultra-Narrow and Conventional Spaced Cotton to Variable Nitrogen Rates. Journal of plant nutrition, 27(4). :743-755.

Rosolem CA (2001) Problemas em nutrição mineral, calagem e adubação do algodoeiro. Informações Agronômicas, 95:10-17.
Silva AV, Chiavegato EJ, Carvalho LH, Furlani Junior, Kondo JI, Salvatierra DK, Tisseli ACPC (2011) Configurações de semeadura e produção e qualidade da fibra do algodoeiro. Semina: Ciências Agrárias, 32(1): 1709-1716.

Silva CAD, Beltrão NEM, Ferreira ACB, Silva ORRF, Suassuna ND (2009) Algodoeiro Herbáceo em Sistema de Cultivo Adensado: Atualidades e Perspectivas. Centro Nacional de Pesquisa de Algodão. Campina Grande: Embrapa Algodão. 35p.

Silva NM, Carvalho LH, Bortoletto N (1986) Parcelamento da cobertura nitrogenada do algodoeiro. Bragantia, 45(2):212-222.

Silva ORRF, Freire EC, Brunetta, E, Brunetta P, Menezes VL, Santos W, Jerônimo JF (2005) Avaliação de uma colheitadeira stripper na colheita de algodão adensado. In: Congresso Brasileiro do Algodão, 5 Anais... Disponível em: <http://www.cnpa.embrapa.br/produtos/algodao/publicaco es/trabalhos_cba5/220.pdf> (Acesso em: 26 fev. 2015).

Silva, RR (2011) Influência de diferentes manejos da adubação nitrogenada na severidade da mancha de ramulária em algodoeiro adensado. UFMS (Trabalho de Conclusão de Curso)

Sofiatti A, Bezerra JRC, Zonta JH, Brandão ZN, Medeiros JC, Azevedo DDP, Silva Filho JL (2011) Adubação nitrogenada de cobertura para o algodoeiro em sistema adensado irrigado. In: CONGRESSO BRASILEIRO DE ALGODÃO, 8, Anais ... CD-ROM. 